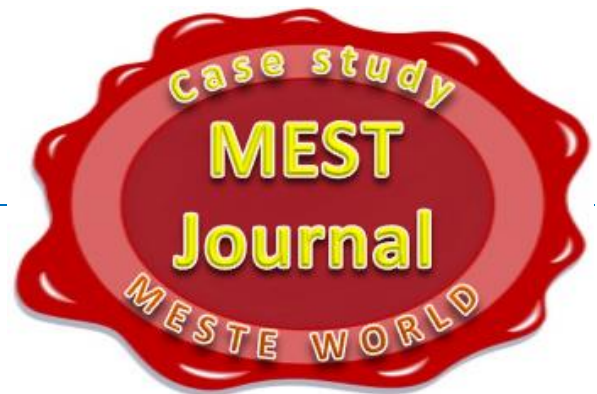

\title{
WINNING TEAM CREATION IN CRISIS CONDITION: CASE STUDY OF PROFESSIONAL BASKETBALL CLUB
}

\author{
Mario Bogdanović \\ University of Split, Faculty of Economics, Split, Croatia
}

If you want to achieve success you have to produce results.

Author

\author{
(c) MESTE NGO \\ JEL category: G32, H12, L83
}

\begin{abstract}
Team sport success is defined by combination of factors: psychophysical state of the players (cognitive, emotional-motivational and corporal), social factors (team cohesion, interpersonal relationships on the relations: management staff-coaching, staff-players, the players between themselves, sometimes the relationships with the public) as situational factors (elements of competitive situation). All of this mentioned factors can decide between victory and defeat in the competitive situation. Management of sport team is especially important in crisis situations (acute result crisis), and for its resolving it is extremely important to diagnose the causes, accept the facts, communicate the problem and in resolving the problem involve all the club members, this means the adaptation of Action Research methodology. So in every efficient management consulting it is needed to determine key problems (by gathering and analysing the broader spectrum of information, identify the causes of the problems and define and conduct the therapy). With such a procedure can be crated the model for resolving the crisis situations in the sports clubs. So this paper present a model for resolving crisis situations in sports teams on the example of one professional basketball club in Croatia. The crisis was solved by crisis identification by variety of measuring instruments and procedure and than followed elimination of its causes. The problems of management staff $(\mathrm{N}=3)$, coaching staff $(\mathrm{N}=2)$ and players $(\mathrm{N}=25$, seven seniors and eighteen juniors/cadets) were first identified, and then corrective activities were undertaken to overcome the crisis. After the acute phase

The address of the author:

Mario Bogdanović

䤵: mbogdan2011@gmail.com

of the crisis was terminated, the club management was consulted in terms of human resources management (recruitment, selection, evaluation of performance and potential,
\end{abstract}


promotion to player positions, motivation and rewarding with an individualised approach to each player) and then some structural interventions were suggested (both in the senior team and the supporting junior/cadet team). This work resulted in the presented model (procedure) for solving not only acute crisis but also structural problems in the sport teams.

Keywords: action research, crisis management, human resources management, organizational consultancy, structural team problems, winning team

\section{INTRODUCTION}

In collective sports success is determined by a set of factors: psycho-physical condition of athletes (cognitive, emotional-motivational, corporal-physiological variables), social variables (team cohesion, relations along the line management-coaches-players, interpersonal relations among players, and sometimes even their relation with the audience), and situational factors such as competitive situation and environmental elements (Wann, 1997). Each of these factors can be a decisive element between victory and defeat. In fact, in collective sports such as basketball, success may be illusive and extremely uncertain and one moment of distraction during the game can instantly turn victory into defeat.

Creating, leading and maintaining a winning sport team involves not only professional knowledge in a particular sport but also some knowledge of applied psychology, human resources management, team leading and ability to diagnose and solve a variety of problems that may be the cause for suboptimal achievement. In fact management competences primarily reflect in creating and maintaining the winning team of the organization (Bogdanović, 2003).

Human resources management and leadership is particularly important in acute crises, i.e. in situations when there is no effectiveness in goal achievement, when results do not meet expectations, and when the set goals are in mutual conflict. Namely, crisis is defined as situation in which effectiveness of a system is below the required or expected one for a longer period of time (Pastuović, 1999). The result crisis is particularly frustrating when it is supported by the awareness that in spite of adequate resources results are not achieved, and that causes for that cannot be discovered, which can lead to psychosocial incidents. No crisis can be solved by criticizing its results but rather by acting on its causes. Therefore, to defuse and overcome it we firstly have to identify its causes. Any approach which contributes to the recognition of the problem and the way to tackle it will be good, but scientific approach will be the most appropriate one because it allows repetition. This approach needs the adaptation Action Research methodology because any change requires action (is directed at achieving this), and successful action is based on analysing the situation correctly, identifying all the possible alternative solutions and choosing the one most appropriate to the situation at hand (Bennett, 1983 according Burnes, 2004, 983).

The first step in facing the crisis and overcoming it is acceptance of reality (facts). It is also necessary to get prepared for the crisis situation psychologically and materially, while good communication will be a precondition of effective therapy where crisis is transformed in an opportunity. Successful organizations have methods to timely recognize, obviate and overcome crisis thus reducing its duration and consequences (Osmanagić-Bedenik, 2003). Naturally, here it is important to stress the constructive character of the crisis as it can also be seen as a challenge in posing new questions (which otherwise may not have been asked at all) and looking for the new answers. Therefore the crisis can be a stimulus for the new beginnings and a new, higher level of operation for the sport team.

To determine the factual conditions in a team a number of variables are used that are seen as important predictors of achievement and creation of a winning team (Kane, 1972; Wurtele, 1986, Baron \& Birne, 1991; Bezinović, 1993; Corsini; 1994; Wann, 1997; Dukić, 1997; Derri, Kioumourtzoglou \& Tzetzis, 1998; Tudor \& Srića 2006). The chosen important key variables are:

- leadership,

- motivation, 
- confidence and self-esteem,

- athlete's personality,

- intelligence,

- stress, anxiety and insults,

- team cohesion.

This work is conceived to provide answers for the concrete problems of a basketball club experiencing a result crisis by the method of cause identification after collecting and analysing a wide range of information on the operating basketball club. In the long run it is also necessary to determine and solve the structural problems of the team in terms of human resources management, by selection, training, evaluation of performance and potential, motivation and rewarding, promotion to player positions, and specific individualized psychological and sociological approach to each athlete.

The purpose is to contribute to creation of the winning team in basketball and in other team sports using the same or similar principles and considering the characteristics of each given sport. The goal of this work is to design an operating model that will integrate knowledge of psychology and human resources management with the empirical data in concrete situations. The model and case study presented here will allow sport and other managers and other people involved in sport to raise their operation to a higher level and base their achievement on the scientific and professional bases.

To be successful in an activity is possible without cognition of what leads to success, but then it does not have scientific and professional basis because it does not allow testing of cause-effects relations, i.e. such approach offers uncertainty in repeating success and it lacks the possibility of generalization and use for other teams or situations. The characteristic of systematic knowledge know what is to be done, how and why it is to be done in order to plan, organize, direct and control some process with a particular purpose (this is management by definition).

The task is to use the empirical basis (psychosocial database) in order to determine the causes for sub-optimal achievement, suggest measures, monitor the proposed measures, and correct them by the time the success or failure of the treatment is perceived. Consequently, the first step is to create the players' psychosocial database as a diagnostic instrument, the second step is to determine the causes of problem by analysis, and the third step is therapeutic and involves proposal of intervention measures to the Club Management with their monitoring and correction.

The problems to be solved by this work spring from the practical need for achievement of the Club Management in the basketball league. Therefore this work is in fact the result of practical professional intervention in the situation when the sport team is expected to achieve better results. The problems involve changes to be carried out on the three levels of the basketball club: Management, Coach, and Players. Therefore the problems are formulated in the following way:

1. Identify the problems of Management, primarily with the players and the Coach. Suggest solution, monitor and correct the situation in accordance with the set goals.

2. Identify the problems of the Coach. Suggest solution, monitor and correct.

3. Identify the problems of the players in terms of selection and activation of their potentials. Determine team cohesion, internal functioning of the team and group efficiency (operationalized through the game results).

\section{METHOD}

This work adapted Action Research methodology which proceeds in spiral steps each of which is composed of a circle of planning, action, and fact-finding about the results of the action. Action Research is an iterative process whereby research leads to action and action leads to evaluation and further research (Lewin, 1946 according Burnes 2004, 984) (Drawing 1).

Namely, according Kurt Lewin's view one cannot understand an organization without trying to change it (Schein 1996, 64). So to have the desired change in the studied basketball club it should adapt methodology which has twopronged processes to give answers on the questions:

a) What is the present situation?

b) What shall we do? 


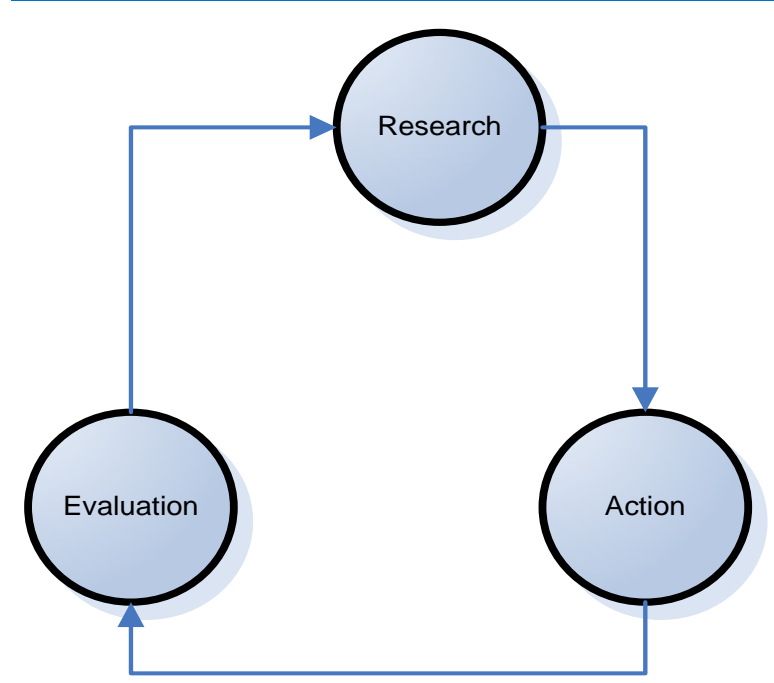

Drawing 1 Process of Action Research (Source: Lewin 1946 according Burnes, 2004, 984.)

First, to have successful action, the situation should be analysing correctly. Second, change requires action and is directed at achieving this.

\section{PARTICIPANTS}

The research involved the Management of a professional Croatian basketball club (3 members), the Coaches (2 members), and basketball players $(25$ members including 7 seniors and 18 juniors/cadets i.e. juniors in further text). The members of the Management were consulted about the problems they wanted to solve. The coaches took part in evaluation of their players, and the main testing consisting of a variety of instruments was carried out on the players:

$$
\begin{aligned}
& 7 \text { seniors aged } 21.79 \text { on average } \\
& \text { (ranging from 18.5 to 25) }{ }^{1} \\
& -\quad 18 \text { juniors aged 16.28 on average } \\
& \text { (ranging from15 to17.5) }
\end{aligned}
$$

As in the Croatian Basketball League five (5) team players play simultaneously, player

\footnotetext{
${ }^{1}$ Originally in the first testing session were 6 seniors, and in second testing session 19 juniors. But very shortly after testing time (senior and junior team members) one older junior player joined full-time to the senior team, so in fact there were 7 tested senior players. The section results represents the originally maded testing and results where were 6 seniors and 19 juniors. Joined junior to the senior team is marked.
}

substitutions are necessary due to personal fouls, tiredness or injuries. These substitutions are provided from the group of junior players.

\section{INSTRUMENTS}

\subsection{General Questionnaire for Basketball Players}

To collect the general data on players (demographic data, psychological characteristics, social characteristics, health condition relevant for athletes) a General Questionnaire for Basketball Players was used, which was constructed by the author on the basis of consulted literature on sport psychology. The questionnaire contains 54 items created by author (see Appendix 1.).

\subsection{Organizational based Self-Esteem (OBSE)}

To measure the team self-esteem the author used the scale Organization Based Self-Esteem (OBSE) designed by Pierce, Gardner, Cummings i Dunham (1989.) The scale consists of 10 items referring to the assessment of the degree to which players consider themselves valuable, useful and efficient team members. Each statement was to be answered on the Likert type continuum with five possible answers (strongly disagree; disagree; neither agree nor disagree; agree; strongly agree; - see Appendix 2.).

\subsection{Problem test}

To measure intellectual functioning of players the author used the standardised Problem Test designed by Bujas, Szabo, Kolesarić (Slap, 1996). The test contains 70 items.

\subsection{Questionnaire on sensitivity to insult}

To measure sensitivity to insults the author used three identical questionnaires for situations when the player is insulted by the coach, by a coplayer, and by an opponent player during the game. The purpose was to determine emotional stability and functioning under stress. This questionnaire was standardised by Levar, A. (1996) in her graduation thesis (see Appendix 3). 


\subsection{Minnesota Multiphasic Personality Inventory (MMPI-201)}

The standardized clinical test MMPI-201 was used to diagnose the existence of a particular problem with the player for selection purposes and to determine normal functioning of personality. The test contains 201 items and 11 scales (lie scale, strange answer scale, control scale, hypochondriasis scale, depression scale, hysteria scale, psychopathic deviation scale, paranoia scale, psychastenia scale, schizophrenia scale, and hypomania scale).

\subsection{Eysenck Personality Questionnaire (EPQ R/A)}

The standardized Eysenck Personality Questionnaire EPQ R/A was used primarily to measure the degree of emotional stability, but also for other personality characteristics:

- psychoticism (callousness, cruelty, indifference to other people, loneliness and insulation, inconsiderateness of danger, lack of empathy, guilt and sympathy)

- extraversion / introversion

- neuroticism (emotional instability)

- lie (propensity to present oneself in socially desirable light)

- $\quad$ adventurism (extraverted impulsiveness)

- criminality (predictor of delinquency)

The questionnaire consists of 106 items.

\subsection{Questionnaire for Coaches}

The questionnaire of player assessment by the coach is an indicator of player quality and the measure of comparison with the achieved results. The questionnaire was obtained from the magazines BASKETBALL [In Croatian.] (30/08/1998) and SUPERSPORT [In Croatian.] (28/08/1998). It is used by journalists to evaluate NBA players in the USA. It consists of 9 items referring to evaluation of basketball player's qualities. Each statement is answered for each individual player on the Likert-type continuum with five possible answers (does not possess the quality at all; does not possess the quality; neither possesses nor does not possess the quality; possesses the quality; possesses the quality to a high degree; - see Appendix 4).

\subsection{Sociometric testing}

Sociometric testing was carried out with both seniors and juniors to determine the social status of each player (in tree contexts: playing in competitive situation, training and free activities) and determine the functioning of the club from the social viewpoint (see Appendix 5).

\subsection{Men as the measuring instrument}

In practical clinical work it is impossible to obtain all the necessary data by standardized instruments. Therefore the clinician steps in and tries to perceive in verbal and non-verbal communication the things that otherwise remain hidden in order to solve the concrete practical problem.

\section{PROCEDURE AND PRELIMINARY PROPOSITIONS ON WHICH THE RESEARCH WAS BASED}

A multi-stage investigation and consulting of all the entities involved in the operational results of the club was carried out including the members of the management, coaches and players. The process of problem identification and goal setting developed in the following way:

A) Goal setting: Arrangement to test the senior team that is directly involved in result achievement.

The team crisis is obvious as despite the plan to win the league championship they have recorded only one victory and four defeats which places them at the bottom of the league rank threatening with fallout from the league and cancellation of sponsorship contracts. Subsequently the junior team is to be tested. In this stage the testing was performed on the first six senior team players by the measuring instruments.

The results obtained in this investigation suggested the following problems:

1. Dissatisfaction with the Management concerning financing, availability of sports equipment, disregard of agreements with the players. 
2. Dissatisfaction with the Coach reflected in the lack of discipline and trust.

3. Problems with players' perception: apathy and lack of confidence in some players, nonindentified leader, low motivation, poor coordination among players resulting in a disrupted team spirit.

\section{B) Response to target problems}

The situation requires intervention. In the meeting with the management it is agreed that the first goal is to win the next two games to overcome the current crisis. The steps to be taken are:

1. The Management guarantees to fulfil all the outstanding obligations to players.

2. The Coach undertakes to talk to the players to get their trust and either take on his role or leave his post. It is to be noted here that the Coach is relatively new (only about a month in this position) so this correction is deemed possible, while the previous coach has resigned due to the team fiasco.

3. The players are informed about the situation, and after a motivating discussion commit to do their part of the job which is to achieve a good result in the next two games.

All this is resolved in a meeting in which the players, the Coach, and the Management take part in the discussion and commit themselves to fulfil their obligations. The Coach and the players discuss their misunderstandings and the Coach is given a vote of confidence. The players are submitted to a motivation practicum. In this practicum the players are mentally energized by the following procedure (similar motivation procedures are also possible and they can all be reduced to a saying: If you want to achieve success you have to produce results.):

"I would like to tell you something that you yourselves have already admitted. As a team you are a bunch of losers that are not worth the money spent on you. However, there is something that puts the odds in your favour. In teams like your, the difference between the winners and the losers is in the mind, which is motivation. By your other features you are either the same or better than the others. The issue is how to activate this difference, how to become motivated.

The chances are that the club fails which will also reduce your price. It is high time you set your heart on winning the next two games at any price. The decision is absolutely yours. Your self-esteem is very low - with it you are bound to lose any game. Nevertheless, you are able to achieve a $30-40 \%$ better result. Let each one of you make up his mind whether he is prepared for that.

The game is the test. I absolutely believe that you can win. If you don't there is no point. If you don't win you are not worth the effort invested in you. That is the difference between professionals and amateurs.

If you don't win, there is no career. Here we are all on the same job. The chances to continue our operation together depend on your winning the game tomorrow (Wednesday) and on Saturday. Encourage your team-mate if you see him giving up!" (The players are asked to commit themselves.)

Committing themselves to victory one by one, the players consciously make up their minds.

In the subsequent games the following results are achieved:

3.1. The first game is won.

3.2. The second game is lost but in overtime, i.e. after a tied score in the regular time, which indicates not an absolute failure but a relative one.

3.3. The third game (against a very tough opponent) is won.

As this sequence of events is relatively successful, the team temporarily overcomes the crisis, which can be at least partly credited to the described activities. During the pause in the basketball season the next stage of the project can be started.

\section{C) Testing of juniors}

As the senior team is completed by junior players, and as they are a guarantee of 
continuation, and since one of the seniors has left for another club (player 1.5.), the testing of juniors is carried out including a newly engaged senior player (player 2.19.).

\section{D) Recovery measures}

After the research is completed the recovery measures are proposed, which will be discussed in more detail in the paper.

\section{RESULTS}

The results obtained by the testing of seniors are shown in the Table 1.

\section{Table 1: Senior team testing results}

Table legend:

No - Player's order number

Brth - Month and year of birth. Age is transformed into numerical codes for anonymity and ethical reasons

Name - Names transformed into numerical codes for anonymity and ethical reasons

Height - according to player's statement

Weight - according to player's statement

LSat - player's life satisfaction

MSSat - player's satisfaction with his material status in the club

SNSat - satisfaction of sport needs in the club IPSat - satisfaction with interpersonal relations in the club
CSat - satisfaction with the Coach

MSat - satisfaction with the management

Rec - perception of importance of recognition in this sport

Ach - perception of high achievement

PS - feeling after practice session

Fit - perception of fitness

Speed - perception of speed

Coord - perception of movement coordination

Shot - perception of shot preciseness

Creat - perception of creativity

Coop - perception of cooperativeness

Mat - perception of maturity

SelfR - self-esteem

Intel - level of intellectual functioning expressed in Z-values

MMPI - results of multifactor personality inventory MMPI

EmSt - emotional stability from EPQ R/A $(\mathrm{M}=11.08 \mathrm{~s}=5.37)$. Negative to $+0.9 \mathrm{Z}$ values denote emotional stability

InsC - perception of insult by the coach

InsTM - perception of insult by teammate

InsOp - perception of insult by opponent player

CoachEv - player evaluation by Coach expressed as arithmetic mean

PCat - classification by age $(S=$ seniors, $\mathrm{C}=$ Cadets, $\mathrm{J}=$ juniors)

ClubExp - perception of club expectation

\begin{tabular}{|c|c|l|l|l|l|l|l|l|l|}
\hline No & Brth & Name & Height & Weight & LSat & MSSat & SNSat & IPSat & CSat \\
\hline 1. & 6.86. & 1.1. & $200 \mathrm{~cm}$ & $93 \mathrm{~kg}$ & 4 & 3 & 2 & 3 & 4 \\
\hline 2. & 1.86. & 1.2. & $198 \mathrm{~cm}$ & $87 \mathrm{~kg}$ & 4 & 3 & 2 & 4 & 2 \\
\hline 3. & 10.86. & 1.3. & $205 \mathrm{~cm}$ & $93 \mathrm{~kg}$ & 4 & 3 & 3 & 4 & 4 \\
\hline 4. & 1.87. & 1.4. & $182 \mathrm{~cm}$ & $74 \mathrm{~kg}$ & 3 & 2 & 3 & 3 & 3 \\
\hline 5. & 6.87. & 1.5. & $201 \mathrm{~cm}$ & $94 \mathrm{~kg}$ & 4 & 3 & 3 & 4 & 4 \\
\hline 6. & 5.90. & 1.6. & $194 \mathrm{~cm}$ & $91 \mathrm{~kg}$ & 5 & 2 & 2 & 2 & 1 \\
\hline
\end{tabular}

\begin{tabular}{|c|c|c|c|c|c|c|c|c|c|}
\hline No & MSat & Rec & Ach & PS & Fit & Speed & Coord & Shot & Creat \\
\hline 1. & 2 & 5 & 3 & 4 & 4 & 4 & 3 & 3 & 2 \\
\hline 2. & 2 & 5 & 3 & 1 & 3 & 4 & 4 & 3 & 3 \\
\hline 3. & 3 & 4 & 4 & 3 & 4 & 4 & 4 & 4 & 3 \\
\hline 4. & 2 & 4 & 4 & 2 & 4 & 3 & 4 & 2 & 4 \\
\hline 5. & 2 & 4 & 4 & 3 & 3 & 4 & 4 & 4 & 4 \\
\hline 6. & 2 & 3 & - & 4 & 4 & 4 & 4 & 5 & - \\
\hline
\end{tabular}


Bogdanović, M. Winning team creation in crisis condition

MEST Journal Vol.2 No.1 pp.37 - 56

\begin{tabular}{|c|c|c|c|c|c|c|c|c|c|}
\hline No & Coop & Mat & SelfR & Intel & MMPI & EmSt & InsC & InsTM & InsOp \\
\hline 1. & 4 & 4 & 3.6 & $+0.25 Z$ & NAD & $-0.39 Z$ & 9.22 & 9.11 & 9.37 \\
\hline 2. & 4 & 2 & 4.3 & $-0.94 Z$ & $\begin{array}{c}\text { Low emotional } \\
\text { energy }\end{array}$ & $-1.32 Z$ & 5.96 & 2.59 & 1.00 \\
\hline 3. & 4 & 3 & 4.0 & $+1.45 Z$ & NAD & $-1.13 Z$ & 2.04 & 2.07 & 3.74 \\
\hline 4. & 4 & 2 & 3.5 & $+1.36 Z$ & NAD & $-0.91 Z$ & 4.04 & 1.59 & 1.00 \\
\hline 5. & 4 & 3 & 4.0 & $-0.39 Z$ & NAD & $-1.50 Z$ & 9.22 & 9.22 & 3.88 \\
\hline 6. & - & 1 & 5.0 & $-0.76 Z$ & $\begin{array}{c}\text { Hypomania (full of } \\
\text { emotional energy) }\end{array}$ & $-1.13 Z$ & 0.85 & 1.19 & 0.00 \\
\hline
\end{tabular}

\begin{tabular}{|c|c|c|c|c|c|c|c|}
\hline No & CoachEv & PCat & ClubExp & No & CoachEv & PCat & ClubExp \\
\hline 1. & 3.00 & S & 4 & 4. & 3.30 & S & 3 \\
\hline 2. & 3.00 & S & 4 & 5. & 3.88 & S & 4 \\
\hline 3. & 2.88 & S & 3 & 6. & 4.11 & S & - \\
\hline
\end{tabular}

The obtained results provide a psycho-social database (which due to its size and confidentiality is shortened presented here) as the basis for the personal record for each player, which besides these data also includes the author's perceptions and analyses (practice sessions, games, conversations). The results obtained by testing junior players are shown in the Table 2.

Table 2 Young players testing results

\begin{tabular}{|r|r|r|r|r|r|r|r|r|r|}
\hline No & \multicolumn{1}{|c|}{ Brth } & Name & Height & Weight & LSat & MSSat & \multicolumn{1}{l}{ SNSat } & IPSat & CSat \\
\hline 1. & 5.96. & 2.1. & $190 \mathrm{~cm}$ & $90 \mathrm{~kg}$ & 4 & 3 & 2 & 3 & 3 \\
\hline 2. & 11.96. & 2.2. & $200 \mathrm{~cm}$ & $90 \mathrm{~kg}$ & 4 & 2 & 3 & 2 & 3 \\
\hline 3. & 4.96. & 2.3. & $181 \mathrm{~cm}$ & $56 \mathrm{~kg}$ & 5 & 2 & 2 & 3 & 2 \\
\hline 4. & 6.96. & 2.4. & $200 \mathrm{~cm}$ & $85 \mathrm{~kg}$ & 4 & 2 & 2 & 4 & 4 \\
\hline 5. & 8.96. & 2.5. & $180 \mathrm{~cm}$ & $75 \mathrm{~kg}$ & 5 & 4 & 3 & 3 & 3 \\
\hline 6. & 9.96. & 2.6. & $188 \mathrm{~cm}$ & $73 \mathrm{~kg}$ & 4 & 4 & 4 & 5 & 4 \\
\hline 7. & 11.96. & 2.7. & $188 \mathrm{~cm}$ & $78 \mathrm{~kg}$ & 4 & 1 & 1 & 1 & 2 \\
\hline 8. & 1.95. & 2.8. & $207 \mathrm{~cm}$ & $90 \mathrm{~kg}$ & 3 & 2 & 3 & 3 & 4 \\
\hline 9. & 11.94. & 2.9. & $195 \mathrm{~cm}$ & $85 \mathrm{~kg}$ & 4 & 4 & 4 & 4 & 4 \\
\hline 10. & 8.95. & 2.10. & $199 \mathrm{~cm}$ & $82 \mathrm{~kg}$ & 4 & 4 & 2 & 4 & 4 \\
\hline 11. & 9.95. & 2.11. & $190 \mathrm{~cm}$ & $73 \mathrm{~kg}$ & 4 & 3 & 2 & 3 & 2.5 \\
\hline 12. & 6.95. & 2.12. & $190 \mathrm{~cm}$ & $80 \mathrm{~kg}$ & 5 & 3 & 4 & 5 & 5 \\
\hline 13. & 5.95. & 2.13. & $191 \mathrm{~cm}$ & $76 \mathrm{~kg}$ & 4 & 3 & 3 & 4 & 3 \\
\hline 14. & 8.95. & 2.14. & $191 \mathrm{~cm}$ & $70 \mathrm{~kg}$ & 2 & 3 & 2 & 5 & 2.5 \\
\hline 15. & 9.94. & 2.15. & $190 \mathrm{~cm}$ & $87 \mathrm{~kg}$ & 4 & - & 3 & 2 & 2 \\
\hline 16. & 9.94. & 2.16. & $186 \mathrm{~cm}$ & $76 \mathrm{~kg}$ & 5 & 4 & 3 & 4 & 4 \\
\hline 17. & 3.96. & 2.17. & $190 \mathrm{~cm}$ & $70 \mathrm{~kg}$ & 4 & 3 & 2 & 2 & 3 \\
\hline 18. & 10.96. & 2.18. & $195 \mathrm{~cm}$ & $78 \mathrm{~kg}$ & 5 & 3 & 3 & 1 & 4 \\
\hline 19. & 9.93. & 2.19. & $202 \mathrm{~cm}$ & $96 \mathrm{~kg}$ & 3 & 1 & 3 & 4 & 3 \\
\hline
\end{tabular}


Bogdanović, M. Winning team creation in crisis condition MEST Journal Vol.2 No.1 pp.37 - 56

\begin{tabular}{|r|r|r|r|r|r|r|r|r|r|}
\hline No & \multicolumn{1}{r|}{ MSat } & \multicolumn{1}{l|}{ Rec } & \multicolumn{1}{c|}{ Ach } & \multicolumn{1}{l|}{ PS } & \multicolumn{1}{l|}{ Fit } & Speed & Coord & \multicolumn{1}{c|}{ Shot } & \multicolumn{1}{c|}{ Creat } \\
\hline 1. & 3 & 5 & 4 & 4 & 3 & 3 & 4 & 4 & 4 \\
\hline 2. & 2 & 5 & 4 & 3 & 3 & 2 & 3 & 4 & 3 \\
\hline 3. & 1 & 5 & 3 & 3 & 3 & 4 & 4 & 3 & 3 \\
\hline 4. & 4 & 4 & 4 & 4 & 2 & 3 & 1 & 2 & 4 \\
\hline 5. & 3 & 4 & 4 & 4 & 3 & 5 & 4 & 3 & 4 \\
\hline 6. & 4 & 5 & 5 & 3 & 3 & 4 & 4 & 2 & 3 \\
\hline 7. & 1 & 2 & 3 & 3 & 3 & 2 & 4 & 4 & 4 \\
\hline 8. & 3 & 5 & 5 & 4 & 1 & 1 & 2 & 3 & 4 \\
\hline 9. & 4 & 4 & 4 & 4 & 3 & 3 & 3 & 3 & 4 \\
\hline 10. & 2 & 5 & 5 & 4 & 4 & 3 & 4 & 2 & 4 \\
\hline 11. & - & 5 & 4 & 3 & 4 & 4 & 4 & 4 & 5 \\
\hline 12. & 3 & 4 & 4 & 5 & 3 & 3 & 4 & 3 & 4 \\
\hline 13. & 2 & 4 & 4 & 2 & 3 & 3 & 4 & 3 & 4 \\
\hline 14. & 4 & 4 & 4 & 1 & 4 & 4 & 3 & 3 & 3 \\
\hline 15. & 3 & 5 & 4 & - & 3 & 3 & 4 & 4 & 4 \\
\hline 16. & 3 & 5 & 5 & 4 & 2 & 2 & 2 & 5 & 4 \\
\hline 17. & 3 & 5 & 4 & 3 & 3 & 3 & 3 & 4 & 4 \\
\hline 18. & 3 & 4 & 5 & - & 2 & 4 & 4 & 4 & 2 \\
\hline 19. & 3 & 5 & 4 & 3 & 2 & 3 & 4 & 4 & 4 \\
\hline
\end{tabular}

\begin{tabular}{|r|r|r|r|r|r|r|r|r|r|}
\hline No & \multicolumn{1}{|c|}{ Coop } & \multicolumn{1}{|c|}{ Mat } & \multicolumn{1}{c|}{ SelfR } & \multicolumn{1}{c|}{ Intel } & MMPI & EmSt & InsC & InsTM & InsOp \\
\hline 1. & 4 & 2 & 4.1 & $-0.48 Z$ & NAD & $-0.01 Z$ & 1.96 & 0.00 & 8.78 \\
\hline 2. & 4 & 2 & 3.8 & $+1.17 Z$ & NAD & $-0.76 Z$ & 6.48 & 4.59 & 3.00 \\
\hline 3. & 3 & 2 & 4.0 & $-0.21 Z$ & NAD & $-1.13 Z$ & 6.74 & 0.00 & 8.70 \\
\hline 4. & 4 & 2 & 3.1 & $+0.71 Z$ & NAD & $-0.19 Z$ & 6.30 & 2.19 & 0.67 \\
\hline 5. & 4 & 2 & 3.6 & $-2.78 Z$ & depression & $-0.95 Z$ & 0.74 & 0.70 & 0.00 \\
\hline 6. & 3 & 2 & 3.5 & $+1.36 Z$ & NAD & $+0.73 Z$ & 6.14 & 7.89 & 1.70 \\
\hline 7. & 4 & 3 & 2.5 & $-1.13 Z$ & Anxiety & $+1.85 Z$ & 4.48 & 1.52 & 3.78 \\
\hline 8. & 4 & 2 & 3.7 & $+0.16 Z$ & NAD & $-0.76 Z$ & 8.59 & 5.59 & 4.19 \\
\hline 9. & 4 & 2 & 4.0 & $-2.23 Z$ & NAD & $-1.13 Z$ & 7.66 & 2.70 & 3.15 \\
\hline 10. & 4 & 3 & 4.0 & $+1.08 Z$ & NAD & $-0.01 Z$ & 0.00 & 1.33 & 0.00 \\
\hline 11. & 4 & 2 & 4.3 & $-1.13 Z$ & NAD & $-1.13 Z$ & 2.88 & 1.19 & 1.70 \\
\hline 12. & 5 & 2 & 3.8 & $+0.62 Z$ & malingerer & $-1.3 Z$ & 0.37 & 0.37 & 10.00 \\
\hline 13. & 4 & 2 & 3.7 & $+0.62 Z$ & NAD & $+0.36 Z$ & 2.62 & 3.93 & 1.22 \\
\hline 14. & 3 & 2 & 4.0 & $-0.48 Z$ & NAD. & $+0.54 Z$ & 3.37 & 0.70 & 3.56 \\
\hline 15. & 4 & 1 & 4.3 & $-0.30 Z$ & NAD & $+0.17 Z$ & 3.59 & 5.37 & 2.52 \\
\hline 16. & 4 & 1 & 4.2 & $-0.30 Z$ & NAD & $-0.95 Z$ & 0.04 & 4.92 & 1.48 \\
\hline 17. & 4 & 2 & 3.8 & $+0.44 Z$ & NAD & $-1.50 Z$ & 5.07 & 3.96 & 1.85 \\
\hline 18. & 4 & - & 3.1 & $-0.39 Z$ & NAD & $-1.13 Z$ & 0.66 & 0.22 & 0.00 \\
\hline 19. & 5 & 2 & 3.0 & $+0.90 Z$ & NAD & $-0.39 Z$ & 7.60 & 4.63 & 8.37 \\
\hline
\end{tabular}




\begin{tabular}{|r|r|c|r|}
\hline No & CoachEv & PCat & ClubExp \\
\hline 1. & 4.00 & $\mathrm{~J} / \mathrm{C}$ & 3 \\
\hline 2. & 3.88 & $\mathrm{C}$ & 3 \\
\hline 3. & 2.44 & $\mathrm{C}$ & 3 \\
\hline 4. & 3.00 & $\mathrm{~J}$ & 3 \\
\hline 5. & 3.33 & $\mathrm{C}$ & - \\
\hline 6. & 4.22 & $\mathrm{C}$ & 3 \\
\hline 7. & 1.78 & $\mathrm{C}$ & 2 \\
\hline 8. & 4.00 & $\mathrm{~J}$ & 4 \\
\hline 9. & 3.89 & $\mathrm{~J}$ & 4 \\
\hline
\end{tabular}

Psychosocial database is also created for juniors/cadets, which is not presented here due to its size and confidentiality.

\section{DISCUSSION}

The created psychosocial database is used to provide concrete suggestions with explanations to the Club Management. Each player is evaluated in terms of his potential and his future role in the club. The following propositions are provided for the senior team:

The player 1.2 for whom the Management has great expectations due to his physical predisposition does not justify them. As can be seen from the database this player does not have the necessary characteristics of a leader, he is emotionally exhausted and lacks perseverance and decisiveness, his motivation is low. Contrary to the beliefs of the Coach and almost all members of the Management, with his under average intellectual functioning he can by no means be the team leader who can drive the team in critical situations. Therefore it is proposed that this player should be replaced by another in the near future.

According to the database, the problem of team leadership could be solved only by the player 1.3 who, in addition to an above average intellectual functioning, has some leadership potential. According to the evaluation of the Coach this player has been deemed incapable of leadership and mainly marginalized, which is why he plays for fun and does not achieve his maximum. It is to be noted that this player used to play for a club

\begin{tabular}{|r|r|c|r|}
\hline 10. & 3.44 & $\mathrm{~J}$ & 3 \\
\hline 11. & 2.22 & $\mathrm{~J}$ & - \\
\hline 12. & 4.00 & $\mathrm{~J}$ & 3 \\
\hline 13. & 3.44 & $\mathrm{~J}$ & 3 \\
\hline 14. & 3.56 & $\mathrm{~J}$ & 3 \\
\hline 15. & 3.88 & $\mathrm{~J}$ & 3 \\
\hline 16. & 3.88 & $\mathrm{~J}$ & 2 \\
\hline 17. & 4.33 & $\mathrm{~J} / \mathrm{C}$ & 3 \\
\hline 18. & 4.00 & $\mathrm{C}$ & 3 \\
\hline 19. & 2.67 & $\mathrm{~S}$ & 3 \\
\hline
\end{tabular}

that was the finalist and runner-up in the national basketball league. As obtaining recognition in sport is important for him this player could easily take on the role of the team leader and thus solve the main and long lasting problem of the Management.

The role of playmaker held by the player 1.4 remains with him because this player has great potential due to his above average intellectual status. However, due to his psychological problems in terms of self-esteem and his low set goals, and due to his pessimistic attitude to life and the club, his endurance and perseverance are reduced so that he does not provide his optimum. This talented playmaker needs therapeutic intervention to make him escape his current crisis.

The player 1.6 is the team locomotion, physically fit, but due to his intellectual functioning at the lower limit of average he cannot make an appropriate team leader in spite of the evaluation by the Coach which is probably made because of his high emotional energy and enthusiasm. What he needs is good leadership and teammates which will, given his high motivation, allow him to function in the best possible way. There are no problems with this player, and he only has to be set in a harmonized teammate atmosphere.

The problem of the player 1.1 is low self-esteem. He needs support to be psychologically lifted.

The player 1.5 has been in the meantime replaced by 2.19 , which is good because a better player is obtained in terms of both intellectual functioning and play. This could be seen 
particularly in the third game when this player drove the team from defeat to victory. This player should not be pressed but rather gently communicated with. If he solves the problem of self-esteem he can drive the team even as a playmaker.

The proposals based on the psycho-social database are presented to the Management, and they completely agree with them. In terms of replacement and completion of the team with new players it is decided to rely on the junior/cadet team. The following proposals are given for the junior team:

From the player 2.6 the Coach has great expectations, which is justifiable. The player has all the necessary predispositions for a leader (above average intellectual functioning, high acceptance from teammates in the game, training, adaptability to new players, good relationship with the audience with some overambitiousness). His greatest problem is low selfesteem and insufficient motivation for playing basketball (for him it is just an interest), but with some corrections and adequate support by the Coach these shortcomings can be easily eliminated. Lower emotional stability results from the self-imposed high criteria and inadequate effort invested (he does not practise regularly). With more frequent practising his fitness and shot would improve. His father is his idol, which can be put to good use. The father should be consulted and asked to stress his pride in his son, the basket player, and to stress the beauty of basketball above all ball games. With more frequent publicly expressed appreciation by the coach and some intimate suggestions that he might benefit from being an acknowledged team leader his motivation and self-esteem might be boosted. It is to be noted that such player as this has been long hoped for by the Coach and by the Management.

The player 2.10 is presented in socially desirable light, although he is not popular when playing and is not unpopular when socializing. The reason for that is his impulsiveness: he loses control when he is upset, acts exclusively at his own discretion, and he is always ready to answer back. His defensive aggressiveness should be transformed into positive energy to enable him to adapt more easily to new team members, not to be dependent on approval and not to be afraid of remarks made by other people. He would be good in the position of a playmaker because he invests a lot of effort and he enjoys practising, which justifies the great expectations of the Coach. Basketball is for him the most important thing in life. It is indicative that he is not dissatisfied with his material status in the club, but resents the Management's inadequate care for sport needs (few practise sessions, poor equipment, and similar variables), which only confirms his wish to make progress in basketball.

As his intellectual functioning is above average, the player 2.2 has a more rational approach to problems. He is not pressed by the expectations of other people; he is not scrupulous, but an independent personality. He plays for pleasure and for significant material benefits that he wants to obtain. He plays for this club because there is no better alternative. Since the club has inadequate means, he is dissatisfied and does not do his best either physically or emotionally. Until the financial aspect is changed he cannot be expected to invest more effort. His advantages are his height, strength, shot preciseness, good coordination of movement, and cooperativeness. His potential allows him to meet the expectations of the Coach in the centre position.

The player 2.11 perceives himself as a high quality player but intellectually he functions below average. The Coach's expectations are very low. Sociometric testing has shown that he is very unpopular in league playing and practice sessions and that the team would not miss him much. Due to his high tolerance to insults, high self-esteem and emotional stability he could be a useful player for practice sessions. He goes in for basketball due to his love for it.

The player 2.14 comes from a family of athletes, his idol is his uncle; he goes in for basketball because he loves it and is fulfilled by it. $\mathrm{He}$ is member of the club exclusively due to the club quality; he is not affected by insults and has high self-esteem. All these advantages show that he is fully committed to basketball. However this player is overworked (he also goes in for body-building): he does not get enough rest and therefore does 
not achieve adequate results, which makes him emotionally and physically exhausted and dispirited (his third life priority is sleeping!). His achievement in practice sessions and games does not correspond to his potential. He has to be explained that he cannot get rid of tiredness by regularly taking vitamins and proteins but that he has to rest to improve his endurance (the main reproach by the Coach is that he is not strong). He could be a good playmaker because he is creative, well-coordinated, fast, precise, and adaptable to new people; he plays well even when away from home and is also highly motivated.

The player 2.16 is popular in league playing and in practice sessions, although he has more strengths as a basketball player (not at all affected by insults, least of all the team members, extraverted, enjoys his relationship with the audience, satisfied with interpersonal relations, practising makes him happy). He would like the Management to have greater expectations from him (he correctly notices that their expectations are lower than Coach's expectations). In any case he will be one of the future first five players. He would be good as a forward as he is satisfied with his shot preciseness, he does not feel bad about making a mistake, he does not analyse his behaviour too much. When he has fewer obligations at school, which prevents his total commitment to basketball, this player can positively surprise the entire club, especially the Management who have made an entirely mistaken low evaluation (2) of him. The player is satisfied with interpersonal relations in the club, but is still less attractive than his brother in play and practice.

The player 2.15 is the most popular for league playing (as well as 2.17), but is generally dissatisfied with the club and the Coach and would like to change everything in their work. He became member of the club after the downfall of his former club. Financial benefits are important (he thinks that he is offered very modest pay and that he gets practically nothing from the club). He is an emotionally stable person, but to some extent introverted, he does not make friends readily, he is not very talkative, he is frequently guilt-ridden, he frequently changes his mood, he is not interested in relationship with the audience, he is right-minded and does not tend to boast about achievements that are not his. Generally he is not affected by insults because nobody insults him, but he would be most affected by an insult coming from the Coach, less by one coming from teammates, and least by insults coming from opponents. It is indicative that he wants a happier life for himself. He also cannot define his feeling after the practice session. He loves basketball and is not interesting in anything except it. He should be made emotionally attached to the club and taught not to be bothered by the past and the mistakes made in previous games. The coach should try to become closer to him and show an interest in him as a person. He would be good in the position of the shooting guard (he is satisfied with his shot preciseness, creativity, cooperativeness, he has the necessary height and weight), but he has to become emotionally attached to the club. The Coach gives him a higher mark than to other players.

The player 2.17 is the best choice for the team leader, he is the most popular player both for league playing and practice sessions. The Coach expects most from him, evaluates most highly his sense for leadership, and the player justifies the expectations. He is not affected by the insults coming from opponents, he enjoys good relationship with the audience, he adapts well to new people, he is creative, cooperative, attends practice sessions daily, affirmation is important for him and he expects progress. He hold that players' dissatisfaction with the club Management can be easily eliminated, the management only have to learn the names of all players and spend more time getting to know them and getting familiar with athletic conditions in the club. Although he is well aware that the club cannot provide better financial benefits at the moment, this aspect is important for him because he wants to make a fortune and achieve fame in basketball. If better conditions were offered elsewhere he would leave the club because he is not very satisfied with interpersonal relations either.

The player 2.8 has all the predispositions for a good centre (height, endurance, cooperativeness, maximal basketball potential and intelligence estimated by the Coach, is not 
prone to injuries). The Coach's expectations are justifiably very high. The player is critical of himself and of other players (he has no idol), although his self-esteem is average his selfevaluation is not as good as his evaluation by the Coach and the Management. Therefore he is willing to practise more and improve himself. The club has recruited him because of his quality (this is his fourth club). He is well aware that the club's expectations from him are high, but he is mistaken in his perception of the Coach's satisfaction with his play. Therefore the Coach has to inform him about his flattering appraisal. The player does not see himself as an easily insulted person, especially if insulted by opponents, but he would be most sensitive to an insult by the Coach. As he plays for money he would be more satisfied if his financial status might be improved. He is not popular in leisure activities as he is not in a habit to go out, he is wilful, and he has more pocket money than anybody else, so other players may have different preferences for leisure activities. His attitude to his own life is ambivalent.

The player 2.1 is very promising and fulfils the high expectations of the Coach. He is an ambitious person (he wants both to obtain a university degree and play basketball professionally) and he is aware of the need for self-development. Emotionally stable and with high self-esteem, he is not prone to injuries. He plays basketball because he is fond of it, and after practice sessions he feels happy and proud. $\mathrm{He}$ is in this club due to the results achieved by the club; this is where he started to play and where he has made his best friend. $\mathrm{He}$ is emotionally attached to the club, so the Management need not worry about his abrupt leaving (although he is not satisfied with the Management). He thinks that the Management should contribute to better sport conditions in the club. He does not consider himself sensitive to insults, but in such situations he would be very sensitive to insults coming from opponent players, therefore he needs help to learn that being sensitive to insults is unreasonable and only helps his opponents. He would be excellent in the position of the shooting guard. The coach highly appreciates his speed and shot preciseness, while he himself is fairly satisfied with them.

The player 2.18 meets the expectations of the Coach and would be excellent in the forward position (he has the best evaluation for speed by the Coach, and he himself is maximally aware of his speed, cooperativeness and creativity). In brief, the player's and the Coach's assessment of efficiency are identical. Although his fitness is not adequate, the player is aware of that and concludes that he should take more practice. $\mathrm{He}$ holds that the audience appreciates his playing, but he does not like contact with the audience. He perceives that he does not play so well away from home but he is not at all sensitive to insults coming from opponent players. It should be investigated what bothers him in the contact with the audience, and then he should be trained to disregard them. He plays basketball because he loves it. He thinks that the Coach should be dominant with his practical and theoretical knowledge, while the Management should be more familiarized with basketball in order to gain his trust. $\mathrm{He}$ is not satisfied with interpersonal relations and consequently other players do not feel a liking for his league playing, and he is not very popular in practice sessions. The player should be observed and advised in social terms in order to eliminate his inadequate behaviour. $\mathrm{He}$ wants to present himself in a socially desirable light and will certainly be anxious to improve his behaviour.

In terms of sociometric testing, the player 2.13 ranks third in popularity for league playing, practice sessions, leisure activities, socializing and closeness. He is satisfied with interpersonal relations, but is inclined to aggressive behaviour. He thinks that he should practise more, but does not have enough time for it due to school obligations and his girlfriend (who is most important in his life as he wants to get married and have two children). The problem is that he feels depressed after practice sessions, which indicates that he expects more from himself and that he is exhausted. He should be additionally motivated for basketball playing, made aware of his strengths (speed, cooperativeness, preciseness, endurance) and used as a shooting guard. He cannot be the first alternative because of his weaker potential, but in case of the first 
alternative's injury he could be used as a substitute because he is note prone to injuries and he wants to gain recognition (as an average A1 league player).

The player 2.4 wants to develop not only in basketball but also in football, and he thinks that he can be more efficient. It is evident that he is not fit enough (it is also the Coach's estimate), but he invests a lot of effort (12 hours a week in the club and 6 hours on his own). The practice sessions exhaust him but he enjoys them, while his problem is his inclination to injuries and to bronchitis. As he goes in for both basketball and football (which due to its aggressiveness may be the cause of his injuries) it is only natural that he is exhausted, therefore he should be directed to play only basketball. He should be explained that his hopes to achieve great success in both sports are unreasonable. He is worried about the financial situation in the club and also by the Management's attitude towards juniors/cadets. He holds that they are neglected, and since this player is intelligent above average the Management should take this remark into consideration. He cannot play among the first five due to his weaker performance away from home, but he should certainly be retained for practice sessions (this is his fifth club, he is here due to his quality) and for possible substitution of the centre (good height, good playing potential, popularity among teammates). This player could be a nice surprise for the Coach and the Management if he commits himself only to basketball, and if he is offered better conditions. In his opinion, the Coach should show more respect to other players.

The player 2.5 is evaluated as mediocre by the coach and the Management does not state anything on their expectations from him. His intellectual functioning is below average, he is anxious about his bodily functions and his health, and he suffers from mild depression. He is very prone to injuries and infective diseases, he suffers from somatic anxiety and takes medication regularly, he is hard to adapt to new people and as such is not suitable for league playing. He can be useful only for practice sessions as he is not sensitive to insults although he is sometimes insulted by other players. He goes in for basketball because he is interested in it, and he is very popular among his teammates for practice sessions. For him practice sessions are the source of joy and pride. He is enduring, cooperative and well-coordinated. He should also be member of the team due to his greatest popularity in leisure activities and socializing. The player is neither adventurous nor outgoing; he is not impulsive and presents himself in a socially desirable manner.

The player 2.7 obtains the lowest evaluation by the Coach. $\mathrm{He}$ is most dissatisfied with the Coach, the Management and interpersonal relations. His motivation is very low, he plays for fun. Recognition is not so important for him, all he wants is to have some fun and thus perhaps achieve success. He does not invest much effort in basketball and does not know what to think about his achievement. His relationship with the Coach is poor, he is prone to aggressive behaviour, he likes to mock and upset others; he lacks empathy and emotional stability, but is highly extroverted and impulsive. His intellectual functioning is below average, during games and practice sessions he is frequently insulted, especially by the Coach. He thinks that the Coach inhibits him. He is rather unpopular among teammates for league playing, practice sessions and leisure activities, and as such he is completely dispensable to the club.

The player 2.12 is most satisfied with the Coach but he is ambivalent to financial status. He is not inclined to injuries and enjoys practising. However, he is not suitable for league playing due to his maximal sensitivity to insults by opponents. He does not like the audience, and is prone to malingering. Although he cannot meet the high expectations of the Coach and the management, he can be a good player for practice sessions (popular among teammates).

The player 2.9 is totally committed to basketball, and among all the teammates he practices most. Of good health, maximally motivated and committed to sport. He is most satisfied with the Coach, the Management, interpersonal relations, and satisfying of needs. Although highly evaluated by the Coach and the Management he cannot meet their high expectations due to his below average intellectual functioning. He is very adaptable to new people but dislikes contact with 
the audience. $\mathrm{He}$ is popular among his teammates for practice sessions and should be retained by the club due to his good characteristics (speed, endurance, creativity, cooperativeness, and shot preciseness) as a good player for practice sessions. His adventurousness, extrovertedness and impulsiveness are reduced, and it is a real pity that so is his intellectual functioning.

For resolving the complex problem of team underachievement, and to have the good diagnosis of organizational situation it should include numerous variables. Namely, without a good information basis it cannot be given good answer on the question: "What should be done?" According to the literature review and researcher experience, this study deals with different types of data: demographic data, standardized and non-standardized psychological data, sociometric data and direct observations data from the field. Such approach is needed to organize good information basis for scientific/professional based organizational consultancy.

To prevent the team achievement crisis, and to resolve the crisis when it occur it should have knowledge about each player (to know where each player can give his optimum, and know his strengths and weakness), and about team cohesion i.e. motivation. To have best results from Action Research methodology it should be used in the systematic and long term way, because organizational consultancy cannot give good answer without properly understanding the organizational situation. Namely, to understand and change (improve) an organization we need knowledge about causes of problems and knowledge about organizational reality - this means numerous information about different variables. According to the collected and analysed information about each player, can be given the answer about the structure (which player should play on which place) of the winning team.

\section{CONCLUSION}

According to the problems of the basketball club in crisis, to change this situation it is adopted the methodological approach of Action Research. So in accordance with the set problems in the basketball team, the solutions are determined in the following manner:

Ad 1) The problems of the club Management are identified. They involve players (their dissatisfaction) and the Coach (who is unprepared for the task as he has not succeeded in building up good relationship with players and has not established true authority and leadership).

These problems are solved by making the interested parties (Management, coach and players) confront at a meeting and each commit to doing their part of the job.

Owing to this the team wins two games out of three, overcomes the acute crisis and gets a reasonable chance to remain in the league.

Ad 2) The survey determines the problem of the Coach (lack of trust and discipline among players). His problem is partly solved at the meeting when all the misunderstandings are discussed and initial trust of players is established by a vote of confidence. In terms of leadership, the Coach is advised about the ways of establishing control.

Ad 3) The problems of players are detected by psychological measuring instruments. For the senior team it is found that team cohesion and team spirit are disrupted. A psychosocial database is created for each player which allows concrete suggestions to be provided for the club management. The same is done for the junior/cadet team. Due to the perceived weaknesses in some functions of human resources management (recruitment, selection, evaluation of players' potential and performance, promotion of players to particular positions, motivation and rewarding by applying individualised approach to each player) some structural interventions are suggested (in the senior team and in the supporting junior team). This leads to the design of a model (procedure) for dealing with result and structural crises in sport teams that is the adapted application of Action Research methodology.

In the concrete practical example the diagnostic procedure and corrective activities are completed, while the basketball club is directed to have periodical sessions in accordance with the 
perceived needs and abilities of the club Management. This study resulted in the presented model (procedure) for solving not only acute crisis but also structural problems in the sport teams. Winning team creation in acute phase means knowledge by which the problem can be resolved in short term time, and winning team creation which has structural problems means knowledge what is needed to resolve the problem in longer term of time. For achieving the best results in terms of preventing and resolving the crisis situations it is highly recommended the Action Research methodology. Action Research methodology starts from the diagnosis of present situation which is often complex with numerous variables. Therefore researcher must be involved in the organization reality, should know the potential causes of the problems - what is not an easy task for researcher who has limited time and resources. But to know the organizational situation, to understand the organization as prerequisite for action (improvement) there is often no other good way. Therefore good scientific/professional answer on the question: "What shall we do?" cannot be given without broad information basis and knowledge what is crucial for success in short and long term time. In this study acute (short time) problem was the result crisis (i.e. motivation) which needed some type of motivation stimulation, and structural (long term) problem was the structure of the winning team which needed broader and deeper study.

\section{WORKS CITED}

Baker, W. (2003). Socijalnim kapitalom do uspjeha: kako crpsti skrivene resurse iz svojih osobnih i poslovnih mreža. [Achieving success through social capital: Taping the hidden recources in your personal and business networks. In Croatian.] Zagreb: Mate, Zagrebačka škola ekonomije i menadžmenta.

Baron, A. R., Byrne, D. (1991). Social Psychology: Understanding Human Interaction. Boston: Allyn \& Bacon.

Bezinović, P. (1993). Samopoštovanje i percepcija osobne kompetentnosti.[Self-esteem and perception of self-competences. In Croatian.] Rijeka: Godišnjak Zavoda za psihologiju Pedagoškog fakulteta u Rijeci, 2, 7-12.

Bogdanović, M. (2003). Menadžment i stvaranje pobjedničkog tima. [Management and creating of winning team. In Croatian.] Zagreb: Poslovna analiza i upravljanje - časopis za menadžment $\mathrm{i}$ njegovu stručnu potporu, 1, 12-17.

Burnes, B. (2004). Kurt Lewin and the Planned Approach to Change: A Re-appraisal. Journal of Management Studies, 41:6 September 2004, 977-1002.

Corsini, J.R.(1994). Encyclopedia of Psychology. Second revised ed. Toronto, Toronto: John Willey \& Sons, Inc., vol. 3.

Derri, V., Kioumourtzoglou E., Tzetzis, G. (1998). Assessment of abilities in basketball: A preliminary study. Perceptual and motor skills, 87(1), 91-95.

Dukić, T. (1997). Verbalna uvredljivost i neki aspekti samopoimanja. [Verbal insult and some aspects of self-concept. In Croatian] (Unpublished master thesis, University of Rijeka). Rijeka: Pedagoški fakultet Sveučilišta u Rijeci.

Greenberg, J., Baron, A.R. (1997). Behavior in organizations. New Jersey: Prentice Hall International.

Kane, J. E. (1972). Psychological aspects of physical education and sport. London: Routhledge \& Kegan Paul.

Košarka [Basketball. In Croatian] (30. 08. 1998.). Sport magazine.

Levar, A. (1996). Verbalna uvredljivost s obzirom na razinu self-monitoringa $i$ spol. [Verbal insult according to self-monitoring and gender. In Croatian]. (Unpublished master thesis, University of Rijeka). Rijeka: Pedagoški fakultet Sveučilišta u Rijeci. 
Lewin, K. (1946). Action research and minority problems. In: Cartwright, D. (Ed.), Resolving Social Conflict. London: Harper \& Row.

Osmanagić-Bedenik, N. (2003). Kriza kao šansa: kroz poslovnu krizu do poslovnog uspjeha. [Crisis as opportunity: through the business crisis to the business success. In Croatian.] Zagreb: Školska knjiga.

Pastuović, N. (1999). Edukologija: Integrativna znanost o sustavu cjeloživotnog obrazovanja i odgoja. [Educology: integral science about life long education system. In Croatian.] Zagreb: Znamen.

Pierce, J.L., Gardner, D.G., Cummings, L.L., Dunham, R.B. (1989). Organizational based self-esteem: Construct definition, measurement and validation. Academy of management Journal, 32(3), 622648.

Schein, E. H. (1996). "Kurt Lewin's change theory in the field and in the classroom: notes towards a model of management learning". System Practice, 9, 1, 27-47.

Supersport [Supersport. In Croatian.] (18. 08. 1998.), Sport magazine.

Tudor, G., Srića, V. (2006). Menadžer i pobjednički tim: čarolija timskog rada. [Manager and winning team: magic of team work. In Croatian.] Zagreb: M.E.P. Consult.

Wann, D. L. (1997). Sport Psychology. New Jersey: Prentice-Hall International.

Wurtelle, S. K. (1986). Self-efficacy and athletic performance: A review. Journal of Social Psychology, 4(3), 290-301.

\section{APPENDICES}

\subsection{Appendix 1}

General questionnaire for basketball players

Name:

Date of birth:

Place of birth:

Address:

Education:

Current profession:

Financial status:

a. dependent (Who supports you?)

b. independent

c. $a$ and $b$

State the monthly amount of money available to you:

- Marital status:

- Number of children:

- Height:

- Weight:

- Smoker: YES/NO (If YES how many cigarettes a day?)

- Do you drink alcohol? YES/NO (If YES how much a day?)

- Do you take any regular medication: YES/NO (If YES what kind?)

- When did you start playing basketball?

- Family tradition in sports: YES/NO (If yes which one?)

- Have you played for other clubs? YES/NO (If YES which ones?)

The following questions are answered by the five degree Likert scale:

not satisfied at all; not satisfied; neither satisfied nor dissatisfied; satisfied; very satisfied.

- Are you satisfied with your life?

- Are you satisfied with your financial status in the club?

- Are your sport needs satisfied by the club?

- Are you satisfied with interpersonal relations in the club?

- Are you satisfied with your relationship with the Coach?

- Are you satisfied with your relationship with the Management?

1. State what could be improved in your relations with the Coach and the Management.

2. State your reasons for playing basketball.

3. Why do you play in this club?
a. Because it is close to my home
b. Due to its quality
c. Because persons close to me play here
d. Because of the pay
e. Something else (State what:)

4. Do you find recognition in this sport important to you?
a. Not important at all
b. Not important
c. Neither important nor unimportant
d. Important
e. Very important

5. What would you like to achieve in this sport? 
6. Do you have an idol in basketball? (If YES who?)

7. Do you have any idols in life? (If YES who?)

8. Which are your activities besides basketball?

9. Rank your activities by their importance for you.

10. Do you aspire to anything else besides your development in basketball? YES/NO (If YES state to what.)

11. How many days and hours a week do you practise basketball?

a) obligatory practice sessions in the club

b) individually

12. Do you think that is adequate for you? YES/NO (If YES explain.)

13. Do you believe that you can realize high achievement in basketball?

a. I don't believe that at all

b. I don't believe that I can realize particularly high achievement

c. I neither believe nor disbelieve that

d. I believe in high achievement

e. I am completely convinced that I can realize high achievement

14. Is there a problem in your life that prevents your doing your best while playing? YES/NO (If YES state what it is.)

15. If you have problems do you think that the club can solve some of them? YES/NO (If yes state which ones.)

16. How highly do your teammates and the Coach evaluate your play?

17. Are the people from your close environment satisfied with your performance in basketball? YES/NO

18. How much is your activity in basketball supported by your family?

a. They are not supportive at all

b. They are not supportive

c. They are neither supportive nor unsupportive

d. They are supportive

e. They are very supportive

19. In your opinion, how high are the Club's expectations from you?
a. Very low
b. Low
c. Neither low nor high
d. High
e. Very high

20. Would you change anything in the club's operation? YES/NO (If YES, explain what.)

21. Do you socialize with your teammates beyond sport activities? YES/NO

22. Is your best friend in this club? (YES/NO) Is he connected with basketball? YES/NO

23. Do your teammates respect you as a person? a. They don't respect me at all

b. They don't respect me

c. They neither respect me nor disrespect me

d. They respect me

e. They admire me

24. Do your teammates criticise you if you do not play well?

a. They criticise me so much that I can hardly bear it

b. They criticize me

c. They do not have any objections

d. They encourage me

25. Do your teammates insult you? YES/NO

26. If yes, how often:
A) DURING
PRACTICE
SESSIONS
a never
b almost never
(less than 10\% sessions)
c infrequently (in 10-30\% sessions)
d averagely (in $30-50 \%$ sessions)
e frequently (in $50-70 \%$ sessions)
$f$ almost always (in $70-100 \%$ sessions)
B) DURING THE GAME
never almost never
infrequently
averagely
frequently
almost always

27. Does the Coach insult you? YES/NO

28. If yes, how often:
A) DURING
PRACTICE
SESSIONS
a never
b almost never (less than 10\% sessions)
c infrequently (in 10-30\% sessions)
d averagely (in $30-50 \%$ sessions)
g frequently (in $50-70 \%$ sessions)
h almost always (in $70-100 \%$ sessions)
B) DURING THE
GAME
never
almost never
infrequently
averagely
frequently
almost always

29. Do your teammates see you as a basketbal player only or as a complete person?

30. What is your relationship with the audience? 

a. They cannot stand me
b. They do not notice me
c. They approve of me
d. They flatter me
e. They are euphoric about me

31. Are you in any way pressed by the Coach or the club Management? YES/NO (If YES, explain.)

32. Are you pressed by anybody from your environment? YES/NO (If YES, who is it?)

33. Do you like contact with audience? YES/NO

34. Do you play worse away from home? YES/NO

35. Do you adapt easily to new people in the team? YES/NO

36. How do you feel after practice sessions?
a. Emotionally exhausted and depressed
b. A little depressed
c. Neither depressed nor happy
d. Happy and proud
e. Very happy

37. Have you got a partner? YES/NO

38. Have you got enough time for your family? YES/NO

\section{The following questions are answered by the five degree Lickert scale:}

not satisfied at all; not satisfied; neither satisfied nor dissatisfied; satisfied; very satisfied.

39. Are you satisfied with your fitness?

40. Are you satisfied with your speed?

41. Are you satisfied with your movement coordination?

42. Are you satisfied with your shot preciseness?

43. Are you a creative player?
a. I am not at all creative
b. I am not very creative
c. I am neither creative nor uncreative
d. I am creative
e. I am very creative

44. Are you cooperative in play?
a. I am not at all cooperative
b. I am not very cooperative
c. I am neither cooperative nor uncooperative
d. I am cooperative
e. I am very cooperative

45. Do you consider yourself a mature player or a developing player?

a. I am very young and have many years ahead to develop as a basketball player

b. I am young and I expect further development

c. I am neither a developing player nor a mature one

d. I am an experienced player

e. I am at the top of my career
46. Do you have any health problems? YES/NO (If YES, state which ones.)

47. Are you prone to injuries?
a. Very prone
b. Prone
c. Neither prone nor non-prone
d. Not prone
e. Not prone at all

48. Are your injuries of acute or chronic type?

49. Do you frequently suffer from recurring injuries? YES/NO

50. Do you frequently suffer from infectious diseases (cold, flu, viroses, etc.)?

\section{Appendix 2}

Questionnaire on Organizational-based selfesteem (according to Pierce, Gardner, Cummings and Dunham, 1989) adapted to sports teams

1. In the team everybody counts on me

2. In the team everybody takes me seriously

3. I am an important team member

4. I am a reliable team member

5. I am a valuable team member

6. I am an efficient team member

7. I am a cooperative team member

8. I am a useful team member

9. I am a trusted team member

10. I can make a change in the team.

\section{Appendix 3}

Questionnaire on sensitivity to insult according to Levar, A. (1996), adapted to sports needs.

Due to the insult repertoire (abusive language), the questonary is not published here. To get it, please, contact the Journal Redaction on e-mail: mest@meste.org or the author on his e-mail: mbogdan2011@gmaill.com

\section{Appendix 4}

Contents of the questionnaire for Coaches adapted from the magazines Supersport of 28/ 08/1998. and Košarka of 30/08/1998.

1. Leadership

2. Creativity

3. Speed

4. Movement coordination

5. Endurance

6. Cooperativeness

7. Preciseness

8. Sport intelligence 


\section{Basketball potential}

\section{Appendix 5}

Sociometric testing adapted to sports needs (Baker, 2003)

1. State the club members with whom you would most like to play the league.

2. With which club members would you not like to play the league?

3. With which club members would you most like to practise?
4. With which club members would you not like to practise?

5. With which club members would you like to pursue leisure activities (e.g. trekking, skiing, shopping, etc.)?

6. With which club members would you not like to pursue leisure activities?

7. With which club members would you like to socialize (talk about personal matters, go out together, etc.)?

8. With which club members would you not like to socialize?
Received for publication:

Revision received:

28.10.2013

Accepted for publication:

08.12 .2013

21.12.2013

\section{How to cite this article?}

Style - APA Sixth Edition:

Bogdanović, M. (2014, 01 15). Winning team creation in crisis conditions: Case study of professional basketball club. (Z. Čekerevac, Ed.) MEST Journal, 2(1), 37-56. doi:10.12709/mest.02.02.01.05

Stile - Chicago Fifteenth Edition

Bogdanović, Mario. "Winning team creation in crisis conditions: Case study of professional basketball club." Edited by Zoran Čekerevac. MEST Journal (MESTE) 2, no. 1 (01 2014): 37-56.

Style - GOST Name Sort:

Bogdanović Mario Winning team creation in crisis conditions: Case study of professional basketball club [Journal] = Winning team creation in crisis condition // MEST Journal / ed. Čekerevac Zoran. Belgrade : MESTE, 01 15, 2014. - 1 : Vol. 2. - pp. 37-56. - ISSN 2334-7958 (Online); ISSN 2334-7171.

Style - Harvard Anglia:

Bogdanović, M., 2014. Winning team creation in crisis conditions: Case study of professional basketball club. MEST Journal, 15 01, 2(1), pp. 37-56.

Style - ISO 690 Numerical References:

Winning team creation in crisis conditions: Case study of professional basketball club. Bogdanović, Mario. [ed.] Zoran Čekerevac. 1, Belgrade : MESTE, 01 15, 2014, MEST Journal, Vol. 2, pp. 37-56. ISSN 2334-7958 (Online); ISSN 2334-7171. 